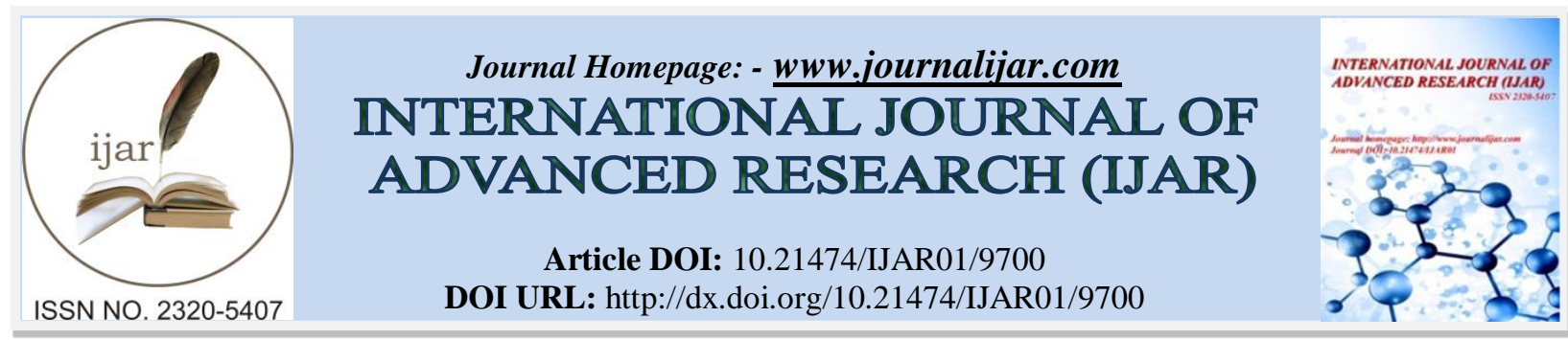

RESEARCH ARTICLE

\title{
LARVAL CYTOTOXICITY AND ACUTE ORAL TOXICITY OF AQUEOUS EXTRACTS OF ELAEIS GUINEENSIS LEAVES AND KHAYA SENEGALENSIS STEM BARK IN WISTAR RATS.
}

\section{S. A. S. Soha ${ }^{1}$, T. V. Dougnon ${ }^{2}$, O. F. Ohouko ${ }^{1}$, S. J. Adouko ${ }^{1,2}$, T. J. Dougnon ${ }^{1,2}$, A. K. I. Youssao ${ }^{3}$, S. Farougou ${ }^{4}$ and T. T. M. Kpodékon ${ }^{1}$.}

1. Research Laboratory in Applied Biology (LARBA), Department of Animal Health and Production, Polytechnic School of Abomey-Calavi, University of Abomey-Calavi, 01 Po.Box 2009 Cotonou, Benin.

2. Research Unit in Applied Microbiology and Pharmacology of natural substance, Research Laboratory in Applied Biology, University of Abomey-Calavi, 01 Po.Box 2009 Cotonou, Benin.

3. Laboratory of Animal Biotechnology and Meat Technology, Department of Animal Health and Production, Polytechnic School of Abomey-Calavi, University of Abomey-Calavi, 01 P.O. Box 2009, Cotonou, Benin.

4. Research Unit on Communicable Diseases, Department of Animal Health and Production, Polytechnic School of Abomey-Calavi, University of Abomey-Calavi, 01 P.O. Box 2009, Cotonou, Benin.

\section{Manuscript Info}

\section{Manuscript History}

Received: 08 July 2019

Final Accepted: 10 August 2019

Published: September 2019

\section{Key words:-}

Cytotoxicity, acute oral toxicity, Elaeis extracts. guineensis, Khaya senegalensis, aqueous

\begin{abstract}
Elaeis guineensis and Khaya senegalensis are two plants used in Africa to treat many bacterial and parasitic diseases. While the data relating to their toxicity are insufficient. This study aimed to determine the toxicity of the aqueous extracts of the leaves of E. guineensis and the stem bark of K. senegalensis. Acute oral toxicity has been evaluated according to OECD guideline 423 at a single dose of $2000 \mathrm{mg} / \mathrm{kg}$ body weight body on Wistar rats. After administration of the extracts, the biochemical data and hematological data were evaluated on days 0,7 and 14. Cytotoxicity of plant extracts was assessed by determining the mortality of Artemia salina, after exposure for 24 hours at different concentrations of extracts. The results showed that after 14 days of experimentation, no mortality and behavior changes were recorded in Wistar rats. However, the rates Hematocrits decreased significantly with the administration of aqueous extracts of Khaya senegalensis $(43.63 \% \pm 1.71$ to $38.57 \% \pm 1.27)$ and Elaeis guineensis $(46.90 \% \pm$ 4.06 at $39.03 \% \pm 3.37$ ). For the Mean Corpuscular Volume, there was an increase between day 0 and day $7 \quad(\mathrm{p}<0.05)$ followed by normalization on day 14 for both extracts. Lethal dose 50 for cytotoxicity were $2.7 \mathrm{mg} / \mathrm{ml}$ and $152 \mathrm{mg} / \mathrm{ml}$ respectively for $\mathrm{K}$. senegalensis and E. guineensis. These data show that the extracts tested can contribute without risk to the management of parasitic diseases, when used at the doses tested.
\end{abstract}

Copy Right, IJAR, 2019,. All rights reserved.

\section{Introduction:-}

In Africa, the control of animal and human diseases is traditionally carried out through the use of medicinal plants (Dibong et al., 2015; Sidi et al., 2017). In Beninese veterinary pharmacopeia, about two thousand and forty-one

Corresponding Author:-S. A. S. Soha.

Address:- Research Laboratory in Applied Biology (LARBA), Department of Animal Health and Production, Polytechnic School of Abomey-Calavi, University of Abomey-Calavi, 01 Po.Box 2009 
(241) species of medicinal plants are used to relieve pathological disorders and clinical signs in animals (Dassou et al., 2015). Among them, Khaya senegalensis and Elaeis guineensis are commonly used to treat parasitic and infectious animal diseases (Dassou et al., 2014, 2014; Houndje et al., 2016; Noudèkè et al., 2017; Umar et al., 2010). Excessive use of medicinal recipes exposes livestock to various accidents due to the different toxic molecules contained in the preparations (Elujoba et al., 2004). This study was carried out to remove doubt about the toxic nature of these two very important medicinal plants in Benin. Its objective is to assess larval cytotoxicity and acute oral toxicity of aqueous extracts of the leaves of Elaeis guineensis and the stem bark of Khaya senegalensis in Wistar rats.

\section{Material and methods:- \\ Plant material}

The stem bark of Khaya senegalensis and the leaves of Elaeis guineensis were used. Organs were collected from the Botanical Garden of the University of Abomey-Calavi in February 2018. The identification was carried out by systematic botanists of the Faculty of Science and Technology of the University of Abomey-Calavi and completed at the botanical laboratory of the National Herbarium of Benin. The stem bark of Khaya senegalensis and the leaves of Elaeis guineensis were dried in the laboratory room, sheltered on sun for 15 days, at a temperature of $25 \pm 1^{\circ} \mathrm{C}$. After drying, plants organs were ground and powders were used for aqueous extractions.

\section{Animal material}

A total of nine (09) female Wistar rats weighing between $146 \mathrm{~g}$ and $214 \mathrm{~g}$ were used. Those rats were acquired at the Institute of Applied Biomedical Sciences (Faculty of Health Sciences, University of Abomey-Calavi) and bread at Research Unit in Applied Microbiology and Pharmacology of Natural Substances (URMAPha) for the experimentation. They were placed in cages of $46 \times 27 \times 17 \mathrm{~cm}^{3}$ size and they had free access to standard food and water. Animals were acclimatized for 14 days prior to the beginning of experiments.

The eggs of Artemia salina (ARTEMIO JBL GmbH D-67141 Neuhofem) were acquired at the Applied Hydrobiology Laboratory of the Faculty of Agricultural Sciences of the University of Abomey-Calavi.

\section{Biological tests \\ Preparation of aqueous extracts}

To prepare the aqueous extracts, $50 \mathrm{~g}$ of powder from each part of the plant (leaves of Elaeis guineensis and stem bark of Khaya senegalensis) were macerated in $500 \mathrm{ml}$ of distilled water on a magnetic stirrer for 48 hours. The resulting homogenate was filtered twice on hydrophilic cotton and once on Whatman $\mathrm{N}^{\circ} 1$ paper. That filtrate was then dried at $50^{\circ} \mathrm{C}$ in an oven and the powder resulting formed the total aqueous extract (Guede-Guina et al., 1995).

\section{Phytochemical screening}

Qualitative phytochemical screening was performed on aqueous extracts using the standard method based on coloring and/or precipitation reactions as described by (Mat Ali et al., 1998) and used by (Kouchade et al., 2017). Phytochemical analysis were carried out at the Laboratory for Applied Biology Research.

\section{Assessment of larval toxicity}

Even at extreme salt doses, freshwater shrimp (Artemia salina) of $13 \mathrm{~mm}$ (maximum size), survive. The methodology used to evaluate the cytotoxicity of the aqueous extracts of the stem bark of Khaya senegalensis and the leaves of Elaeis guineensis was inspired by the work of (Kawsar et al., 2008). Experimentation was carried out on hatching larvae obtained from $10 \mathrm{mg}$ of Artemia salina eggs (ARTEMIO JBL GmbH D-67141 Neuhofem) under continuous agitation in 1 liter of seawater for 48 hours. To assess the cytotoxicity of extracts, series dilutions were made with sterile distilled water after $50 \%$ dilution in T1 to T10 numbered test tubes from a concentration of 50 $\mathrm{mg} / \mathrm{ml}$ extracts. $1 \mathrm{ml}$ of each series dilution prepared from a $50 \mathrm{mg} \cdot \mathrm{ml}-1$ parent solution was added to $1 \mathrm{ml}$ of seawater containing 16 larvae to an extract. The number of surviving larvae was counted after 24 hours of incubation under medium agitation $(100-150 \mathrm{rpm}) . \mathrm{LC}_{50}$ was determined from the regression line obtained from the representative number of surviving larvae curve based on the concentration of extracts. To interpret these results, correlation grids combining the degree of $\mathrm{LC}_{50}$ toxicity were proposed by (Moshi et al., 2004). The correlation grid is presented in Table 1.

Table 1:-Toxicity grid

\begin{tabular}{|l|l|}
\hline Toxicity grid & Lethal Concentration $50\left(\mathrm{LC}_{50}\right)$ \\
\hline Non-toxic extract & LC50 $\geq 0.1 \mathrm{mg} / \mathrm{ml}$, \\
\hline
\end{tabular}




\begin{tabular}{|l|l|}
\hline Moderately toxic extract & $0.1 \mathrm{mg} / \mathrm{ml}>\mathrm{LC} 50 \geq 0.050 \mathrm{mg} / \mathrm{ml}$ \\
\hline Highly toxic extract & $\mathrm{LC} 50<0.01 \mathrm{mg} / \mathrm{ml}$ \\
\hline
\end{tabular}

\section{Study of oral acute toxicity in Wistar rats}

The methodology used was based on the OECD guideline 423. Wistar rats were initially fasted 24 hours before gavage. Nine (09) Wistar rats were divided into three (03) group of three (03) rats. The following treatments had been applied:

1. The control group received distilled water $(1 \mathrm{ml} / 100 \mathrm{~g})$;

2. Groups 1 and 2 were treated with the aqueous extract of the stem bark of Khaya senegalensis and the leaves of Elaeis guineensis at a concentration of $2000 \mathrm{mg} / \mathrm{kg}$, respectively.

After orally administration of a single dose of the aqueous extracts, Wistar rats were placed in individual cages for observation. These observations concerned the behavior and general condition of the animals. Mortality was assessed for 48 hours after extracts were administered. The body weight of each animal was recorded before the extracts were administered, 7 days after administration and 14 days after administration.

\section{Evaluation of hematological and biochemical parameters in Wistar rats}

This activity consisted of an analysis of blood sampled from Wistar rats in the different experimental group. These blood samples were taken on $100 \%$ of the rats in each group prior to administration of the aqueous extracts (day 0 ), on day 7 and day 14 after administration of the aqueous extracts at a concentration of $2000 \mathrm{mg} / \mathrm{kg}$. The complete numeration was made from $2 \mathrm{ml}$ of blood taken from $8.5 \%$ EDTA tubes with an automate Coulter S plus type. The measured parameters were: The number of red blood cells (NR), hemoglobin (Hb), hematocrit (Hte), white blood cells (NB), mean of Globular Volume (VGM), mean of hemoglobin corpuscular concentration (CCMH), mean of hemoglobin corpuscular content (TCMH), neutrophil polynuclear (PN), lymphocytes (L) and monocytes (M). In order to establish biochemical parameters, $2 \mathrm{ml}$ of blood was collected from Wistar rats at the eye vein level. Blood glucose levels, uremia, creatinine content, total cholesterol, HDL, GOT and GPT were the main biochemical parameters evaluated in these rats.

Histological study of the liver and kidney of Wistar rats subjected to acute oral toxicity test with aqueous extracts from leaves of Elaeis guineensis and stem bark of Khaya senegalensis

Histological study was made at the histopathology laboratory of Institute of Applied Biomedical Sciences (ISBA) of the Faculty of Health Sciences of Benin and the methodology used was based on the work of (Kiernan, 2015). One animal in each group was randomly selected and dissected by a central abdominal incision. Histological analysis of liver and kidney was performed using the basic techniques described by (Smith and Bruton, 1977). The kidney and liver samples were collected and immediately fixed in Bouin fluid and 10\% buffered formaldehyde in labeled plastic bottles. The tissues were dehydrated at graduated xylene concentrations, included in molten paraffin and cut to 5 $\mu \mathrm{m}$. Tissues collected were attached to glass blades and stained with hematoxyline and eosine for optical microscopy at a magnification of 400x. Microphotographs of some of the tissues were taken using a cameraequipped microscope.

\section{Statistical analysis:-}

After encoding with Microsoft Office Excel 2013, data were analyzed with the SAS software (2013). For biochemical and hematological parameters and weight evolution, a variance analysis was performed by the Proc GLM procedure. Fisher's F-test was used to determine the significance of the effect of aqueous extracts on variables and comparisons between averages were made by student's t-test.

\section{Results:-}

Larval cytotoxicity of aqueous extracts of stem bark of Khaya senegalensis and leaves of Elaeis guineensis Mortality of Artemia salina shrimp exposed to aqueous extracts of plants followed a dose-response relationship and the number of dead larvae increased with the concentration of extracts increases. The mean of lethal concentration $\left(\mathrm{LC}_{50}\right)$ for each extract was determined using the regression equation $\mathrm{Y}=\mathrm{aX}+\mathrm{b}$ (Figures 1 and 2 ). 


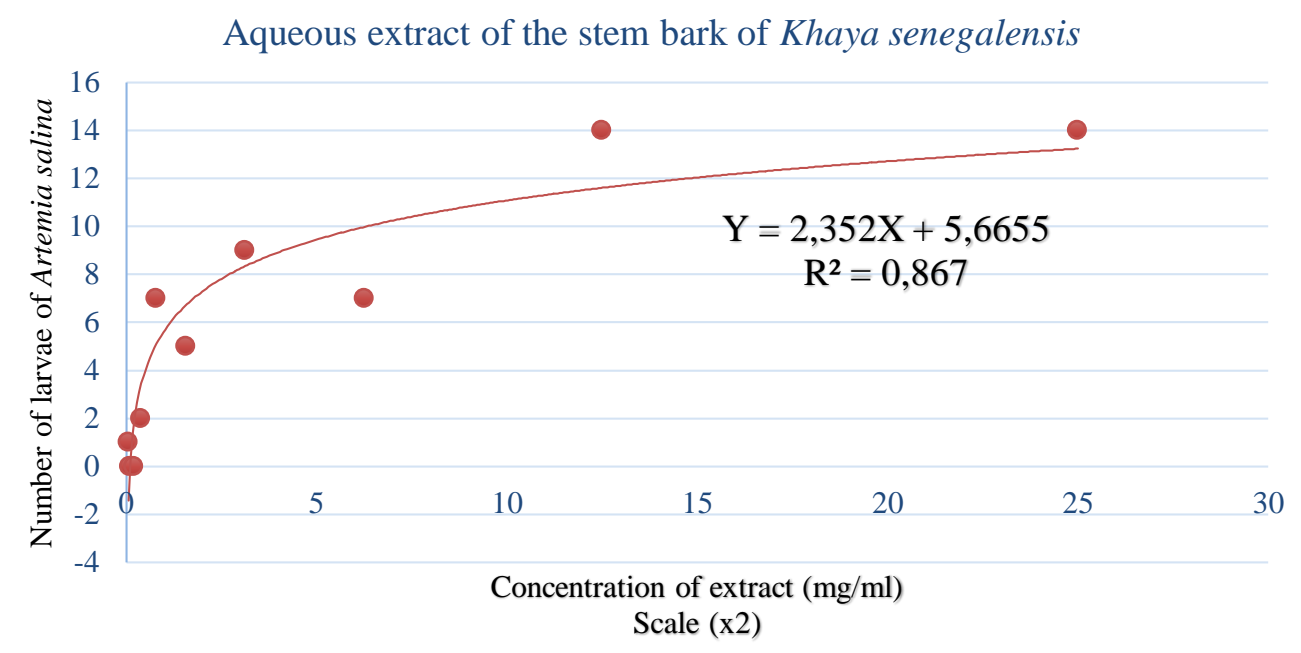

Figure 1:-Logarithmic larval cytotoxicity curve of the aqueous extract of the stem bark of Khaya senegalensis on Artemia salina

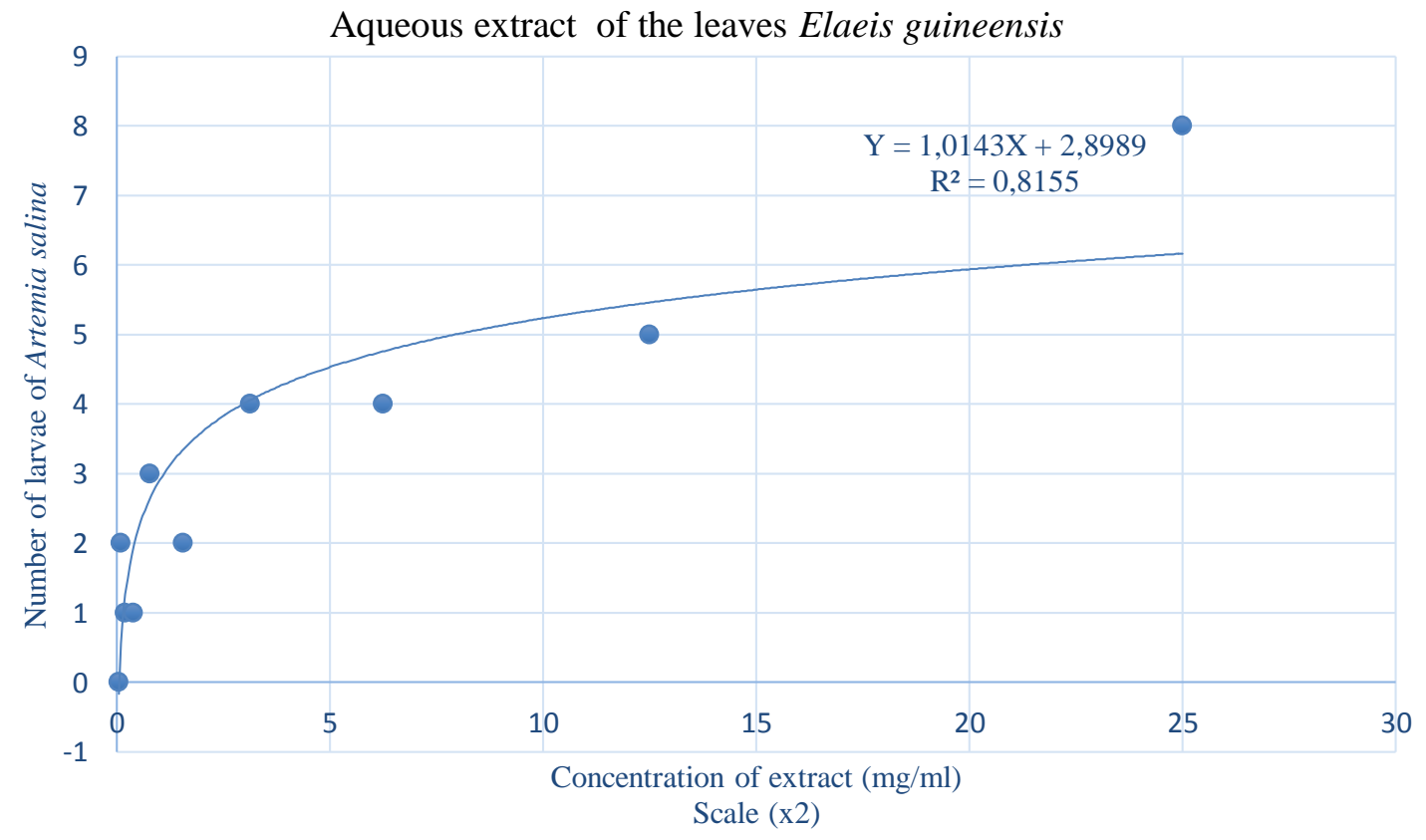

Figure 2:-Logarithmic larval cytotoxicity curve of the aqueous extract of leaves of Elaeis guineensis on Artemia

Determination of Lethal Concentration 50 (LC50)

salina

Lethal concentration 50 is the extract concentration needed to kill $50 \%$ of Artemia salina larvae. Concentrations that cause the death of half $(8)$ of the 16 introduced larvae $\left(\mathrm{LC}_{50}\right)$ for each extract were determined using the regression equation $\mathrm{Y}=\mathrm{a} \ln (\mathrm{X})+\mathrm{b}$ (Figures 1 and 2). Lethal concentrations 50 of the aqueous extracts of leaves of Elaeis guineensis and stem bark of Khaya senegalensis were $152.8 \mathrm{mg} / \mathrm{ml}$ and $2.7 \mathrm{mg} / \mathrm{ml}$ respectively (Table 2). $\mathrm{LC}_{50} \geq 0.1$ $\mathrm{mg} / \mathrm{ml}$ is found for all extracts. 
Table 2:-Lethal concentrations 50 of the aqueous extracts of the stem bark of Khaya senegalensis and leaves of Elaeis guineensis

\begin{tabular}{|l|l|l|l|l|}
\hline Aqueous extracts & $\mathrm{a}$ & $\mathrm{b}$ & $\mathrm{Y}$ & $\mathrm{LC}_{50}(\mathrm{mg} / \mathrm{ml})$ \\
\hline Elaeis guineensis & 1,0143 & 2,8989 & 8 & 152,80807 \\
\hline Khaya senegalensis & 2,352 & 5,6655 & 8 & 2,69813157 \\
\hline
\end{tabular}

$\mathrm{LC}_{50}$ : Lethal Concentration 50

Phytochemical screening of used plants

Phytochemical screening of the stem bark of Khaya senegalensis revealed the presence of tannins, anthocyanins, leuco-anthocyanins, saponins, steroids, and anthracenic derivatives. The analysis of the leaves of Elaeis guineensis showed the presence of tannins, heterosides, saponins, flavonoids, steroids, reducing compound, coumarin, anthracenic derivatives, terpenoids and alkaloids.

Acute oral toxicity of aqueous extracts of the stem bark of Khaya senegalensis and leaves of Elaeis guineensis on Wistar rats

\section{Evaluation of behavioral parameters}

Oral administration of a single dose of $2000 \mathrm{mg} / \mathrm{kg}$ of the aqueous extracts of the stem bark of Khaya senegalensis and leaves of Elaeis guineensis did not cause any behavioral changes (grooming, pelage, tremor, motility, noise reaction, stool appearance) in experimental Wistar rats. No signs of toxicity such as a dying appearance were found. During the 14 days of observation after gavage, no mortality was recorded among rats that continued to lead an apparently normal life. No clinically detectable signs were observed.

\section{Mortality in constituted batches}

During the 14 days of observation after gavage, no deaths were observed in Wistar rats gaved with aqueous extracts of the leaves of Elaeis guineensis and the stem bark of Khaya senegalensis at a concentration of $2000 \mathrm{mg} / \mathrm{kg}$.

\section{Evolution of weight growth of experimental Wistar rats}

Gavage of Wistar rats with distilled water at $1 \mathrm{ml} / 100 \mathrm{~g}(2000 \mathrm{mg} / \mathrm{kg})$ of body live weight did not cause any alteration in the weight status of the control lot animals. There was a non-significant change of weight in control group of rats $(175.33 \mathrm{~g} \pm 34.95-180.00 \pm 22.00)$ between day 0 (before distilled water gavage) and day 14 (14th day after distilled water gavage). Gavage of Wistar rats with aqueous extract of the stem bark of Khaya senegalensis at a concentration of $2000 \mathrm{mg} / \mathrm{kg}$ live weight caused a decrease in body weights $(164.67 \mathrm{~g} \pm 16.50-153.67 \mathrm{~g} \pm 12.34)$ in rats treated after 14 days of experimentation ( $>0.05)$. Gavage treatment of Wistar rats with aqueous extract of the leaves of Elaeis guineensis at $2000 \mathrm{mg} / \mathrm{kg}$ live weight resulted in an increase of the body weight of rats on day 7 post-gavage from $195.67 \mathrm{~g} \pm 22.03$ on day to $196.67 \mathrm{~g} \pm 26.27$ on day 7 then a decrease of the weight of these animals $(194.00 \mathrm{~g} \pm 23.43)$ at the 14 th post-gavage day $(\mathrm{p}>0.05)$. The different results are presented in Table 3 .

Table 3:-Effects of aqueous extracts of the stem bark of Khaya senegalensis and the leaves of Elaeis guineensis on the weight of Wistar rats.

\begin{tabular}{|l|l|l|l|l|l|l|l|}
\hline \multirow{2}{*}{ Groups } & D0 & D7 & D14 & Significance \\
\cline { 2 - 7 } & Weight $(\mathbf{g})$ & $\mathbf{N}$ & Weight $(\mathbf{g})$ & $\mathbf{N}$ & Weigt $(\mathbf{g})$ & $\mathrm{N}$ & \\
\hline $\begin{array}{l}\text { Control (distilled } \\
\text { water) }\end{array}$ & $175.33 \pm 34.95^{\mathrm{a}}$ & 3 & $179.00 \pm 24.25^{\mathrm{a}}$ & 3 & $180.00 \pm 22.00^{\mathrm{a}}$ & 3 & $\mathrm{NS}$ \\
\hline $\begin{array}{l}\text { Khaya } \\
\text { senegalensis }\end{array}$ & $164.67 \pm 16.50^{\mathrm{a}}$ & 3 & $161.33 \pm 15.01^{\mathrm{a}}$ & 3 & $153.67 \pm 12.34^{\mathrm{a}}$ & 3 & $\mathrm{NS}$ \\
\hline Elaeis guineensis & $195.67 \pm 22.03^{\mathrm{a}}$ & 3 & $196.67 \pm 26.27^{\mathrm{a}}$ & 3 & $194.00 \pm 23.43^{\mathrm{a}}$ & 3 & $\mathrm{NS}$
\end{tabular}

D0 : Day 0; D7 : Day 7; D14: Day 14;g : gramme; N : Size ; NS : Not significant, values of the same line followed by different letters are significantly different at the threshold of $5 \%$.

Effects of aqueous extracts of the stem bark of Khaya senegalensis and the leaves of Elaeis guineensis on hematological parameters of Wistar rats

The average levels for the different hematological parameters are presented in Table 4. These different parameters studied did not show any significant variation with the control group throughout the experimental period. Wistar rats gaved with aqueous extracts of the stem bark of Khaya senegalensis and the leaves of Elaeis guineensis recorded significant changes in Packed Cell Volume (PCV), Mean of Corpuscular Hemoglobin Concentration (MCHC), and 
Mean Corpuscular Volume (MCV) ( $\mathrm{p}<0.05)$. Packed Cell Volume (PCV) and Mean Corpuscular Volume (MCV) increased on day 7 and fell on day 14 of the experiment $(\mathrm{p}<0.05)$. The Mean of Hemoglobin Corpuscular Concentration declined on the 7th day of the experiment, with an increase on the 14th day of the test. Aqueous extracts of the leaves of Elaeis guineensis resulted in a significant decrease in of monocytes on day 7 of the experiment followed by a return to normal levels on day 14 of the test $(\mathrm{p}<0.01)$.

Table 4:-Effect of aqueous extracts of the stem bark of Khaya senegalensis and the leaves of Elaeis guineensis on hematological parameters in Wistar rats

\begin{tabular}{|c|c|c|c|c|c|c|c|c|c|c|c|}
\hline & \multicolumn{11}{|c|}{ Hematological parameters } \\
\hline $\begin{array}{l}\text { Grou } \\
\text { ps }\end{array}$ & $\mathbf{T}$ & $\begin{array}{l}\text { RBC } \\
\left(10^{6}\right. \\
/ \mu \mathrm{l})\end{array}$ & $\begin{array}{l}\mathrm{Hb} \\
(\%)\end{array}$ & $\begin{array}{l}\text { PCV } \\
(\%)\end{array}$ & $\begin{array}{l}\text { MCH } \\
\text { C } \\
\text { (g/dl) }\end{array}$ & $\begin{array}{l}\text { MCV } \\
\text { (fl) }\end{array}$ & $\begin{array}{l}\text { MCH } \\
\text { (pg) }\end{array}$ & $\begin{array}{l}\text { WBC } \\
\left(\mathbf{1 0}^{3}\right. \\
/ \mu \mathrm{l})\end{array}$ & PN (\%) & L (\%) & M (\%) \\
\hline \multirow[t]{3}{*}{$\begin{array}{l}\text { Contr } \\
\text { ol }\end{array}$} & $\begin{array}{l}\mathrm{D} \\
0\end{array}$ & $\begin{array}{l}8.16 \pm \\
0.23 \mathrm{a}\end{array}$ & $\begin{array}{l}14.67 \\
\pm \\
0.64 \mathrm{a}\end{array}$ & $\begin{array}{l}46.07 \\
\pm 1.74 \mathrm{a}\end{array}$ & $\begin{array}{l}31.83 \pm \\
0.91 \mathrm{a}\end{array}$ & $\begin{array}{l}56.47 \pm \\
1.20 \mathrm{a}\end{array}$ & $\begin{array}{l}17.97 \\
\pm \\
0.29 \mathrm{a}\end{array}$ & $\begin{array}{l}12.83 \pm \\
4.29 \mathrm{a}\end{array}$ & $\begin{array}{l}26.00 \pm \\
17.69 \mathrm{a}\end{array}$ & $\begin{array}{l}67.33 \pm \\
20.50 \mathrm{a}\end{array}$ & $\begin{array}{l}6.67 \pm \\
4.16 \mathrm{a}\end{array}$ \\
\hline & $\begin{array}{l}\mathrm{D} \\
7\end{array}$ & $\begin{array}{l}8.57 \pm \\
0.24 \mathrm{a}\end{array}$ & $\begin{array}{l}14.20 \\
\pm \\
0.36 \mathrm{a}\end{array}$ & $\begin{array}{l}46.50 \\
\pm 1.04 \mathrm{a}\end{array}$ & $\begin{array}{l}31.03 \pm \\
1.27 \mathrm{a}\end{array}$ & $\begin{array}{l}59.30 \pm \\
1.37 \mathrm{a}\end{array}$ & $\begin{array}{l}18.40 \\
\pm \\
0.46 \mathrm{a}\end{array}$ & $\begin{array}{l}11.00 \pm \\
2.55 \mathrm{a}\end{array}$ & $\begin{array}{l}25.33 \pm \\
4.16 \mathrm{a}\end{array}$ & $\begin{array}{l}72.67 \pm \\
6.11 \mathrm{a}\end{array}$ & $\begin{array}{l}2.00 \pm \\
2.00 \mathrm{ab}\end{array}$ \\
\hline & $\begin{array}{l}\mathrm{D} \\
1 \\
4\end{array}$ & $\begin{array}{l}8.37 \pm \\
0.26 \mathrm{a}\end{array}$ & $\begin{array}{l}14.10 \\
\pm \\
0.52 \mathrm{a}\end{array}$ & $\begin{array}{l}46.70 \\
\pm 0.61 \mathrm{a}\end{array}$ & $\begin{array}{l}31.33 \pm \\
1.00 \mathrm{a}\end{array}$ & $\begin{array}{l}57.67 \pm \\
2.89 \mathrm{a}\end{array}$ & $\begin{array}{l}19.47 \\
\pm \\
1.34 \mathrm{a}\end{array}$ & $\begin{array}{l}8.67 \quad \pm \\
2.97 \mathrm{a}\end{array}$ & $\begin{array}{l}19.00 \pm \\
5.57 \mathrm{a}\end{array}$ & $\begin{array}{l}72.33 \pm \\
6.43 \mathrm{a}\end{array}$ & $\begin{array}{l}8.67 \pm \\
1.53 \mathrm{ac}\end{array}$ \\
\hline \multicolumn{2}{|c|}{ Threshold } & NS & NS & NS & NS & NS & NS & NS & NS & NS & NS \\
\hline \multirow{3}{*}{$\begin{array}{l}\text { K. } \\
\text { seneg } \\
\text { alensi } \\
\text { S }\end{array}$} & $\begin{array}{l}\mathrm{D} \\
0\end{array}$ & $\begin{array}{l}7.93 \pm \\
0.55 \mathrm{a}\end{array}$ & $\begin{array}{l}13.90 \\
\pm \\
0.52 \mathrm{a}\end{array}$ & $\begin{array}{l}43.63 \\
\pm 1.71 \mathrm{a}\end{array}$ & $\begin{array}{l}31.87 \pm \\
0.12 \mathrm{a}\end{array}$ & $\begin{array}{l}54.80 \pm \\
2.75 \mathrm{a}\end{array}$ & $\begin{array}{l}17.47 \\
\pm \\
0.91 \mathrm{a}\end{array}$ & $\begin{array}{l}8.20 \pm \\
0.98 \mathrm{a}\end{array}$ & $\begin{array}{l}12.00 \pm \\
8.89 \mathrm{a}\end{array}$ & $\begin{array}{l}83.33 \\
\pm 11.02 \mathrm{a}\end{array}$ & $\begin{array}{l}3.67 \pm \\
3.06 \mathrm{a}\end{array}$ \\
\hline & $\begin{array}{l}\mathrm{D} \\
7\end{array}$ & $\begin{array}{l}7.51 \pm \\
0.36 \mathrm{ab}\end{array}$ & $\begin{array}{l}13.37 \\
\pm \\
0.40 \mathrm{a}\end{array}$ & $\begin{array}{l}46.10 \\
\pm 0.89 a\end{array}$ & $\begin{array}{l}29.00 \pm \\
0.66 b\end{array}$ & $\begin{array}{l}61.47 \pm \\
2.31 \mathrm{~b}\end{array}$ & $\begin{array}{l}17.83 \\
\pm \\
1.01 \mathrm{a}\end{array}$ & $\begin{array}{l}7.60 \pm \\
3.58 \mathrm{a}\end{array}$ & $\begin{array}{l}16.00 \pm \\
4.00 \mathrm{a}\end{array}$ & $\begin{array}{l}82.67 \pm \\
4.16 \mathrm{a}\end{array}$ & $\begin{array}{l}1.33 \pm \\
1.15 \mathrm{a}\end{array}$ \\
\hline & $\begin{array}{l}\mathrm{D} \\
1 \\
4\end{array}$ & $\begin{array}{l}7.06 \pm \\
0.33 b\end{array}$ & $\begin{array}{l}13.13 \\
\pm \\
0.23 \mathrm{a}\end{array}$ & $\begin{array}{l}38.57 \\
\pm \\
1.27 \mathrm{~b}\end{array}$ & $\begin{array}{l}34.13 \pm \\
1.50 \mathrm{c}\end{array}$ & $\begin{array}{l}54.67 \pm \\
1.15 \mathrm{a}\end{array}$ & $\begin{array}{l}18.67 \\
\pm \\
1.19 \mathrm{a}\end{array}$ & $\begin{array}{l}6.43 \quad \pm \\
0.83 \mathrm{a}\end{array}$ & $\begin{array}{l}16.00 \pm \\
3.61 \mathrm{a}\end{array}$ & $\begin{array}{l}78.67 \pm \\
4.93 \mathrm{a}\end{array}$ & $\begin{array}{l}5.33 \pm \\
2.08 \mathrm{a}\end{array}$ \\
\hline \multicolumn{2}{|c|}{ Threshold } & NS & NS & $* *$ & $* *$ & $*$ & NS & NS & NS & NS & NS \\
\hline \multirow[t]{3}{*}{$\begin{array}{l}\text { E. } \\
\text { guinee } \\
\text { nsis }\end{array}$} & $\begin{array}{l}\mathrm{D} \\
0\end{array}$ & $\begin{array}{l}8.41 \pm \\
1.02 \mathrm{a}\end{array}$ & $\begin{array}{l}13.90 \\
\pm \\
0.89 \mathrm{a}\end{array}$ & $\begin{array}{l}46.90 \\
\pm 4.06 \mathrm{a}\end{array}$ & $\begin{array}{l}29.77 \pm \\
3.20 \mathrm{a}\end{array}$ & $\begin{array}{l}55.93 \pm \\
2.05 \mathrm{a}\end{array}$ & $\begin{array}{l}16.70 \\
\pm \\
2.26 \mathrm{a}\end{array}$ & $\begin{array}{l}10.03 \pm \\
5.12 \mathrm{a}\end{array}$ & $\begin{array}{l}17.33 \pm \\
6.43 \mathrm{a}\end{array}$ & $\begin{array}{l}74.67 \pm \\
6.66 \mathrm{a}\end{array}$ & $\begin{array}{l}8.00 \pm \\
1.00 \mathrm{a}\end{array}$ \\
\hline & $\begin{array}{l}\mathrm{D} \\
7\end{array}$ & $\begin{array}{l}8.20 \pm \\
0.36 \mathrm{a}\end{array}$ & $\begin{array}{l}14.03 \\
\pm \\
0.70 \mathrm{a}\end{array}$ & $\begin{array}{l}47.53 \\
\pm 2.11 \mathrm{a}\end{array}$ & $\begin{array}{l}29.67 \pm \\
0.25 \mathrm{a}\end{array}$ & $\begin{array}{l}57.80 \pm \\
0.26 \mathrm{ab}\end{array}$ & $\begin{array}{l}17.23 \\
\pm \\
0.25 \mathrm{a}\end{array}$ & $\begin{array}{l}10.63 \pm \\
0.21 \mathrm{a}\end{array}$ & $\begin{array}{l}23.33 \pm \\
6.35 \mathrm{a}\end{array}$ & $\begin{array}{l}71.67 \pm \\
1.53 \mathrm{a}\end{array}$ & $\begin{array}{l}2.00 \pm \\
1.00 \mathrm{~b}\end{array}$ \\
\hline & $\begin{array}{l}\mathrm{D} \\
1 \\
4 \\
\end{array}$ & $\begin{array}{l}7.23 \pm \\
0.76 \mathrm{a}\end{array}$ & $\begin{array}{l}13.73 \\
\pm \\
0.85 \mathrm{a}\end{array}$ & $\begin{array}{l}39.03 \\
\pm \\
3.37 \mathrm{~b}\end{array}$ & $\begin{array}{l}35.20 \pm \\
1.25 b\end{array}$ & $\begin{array}{l}54.00 \pm \\
1.00 \mathrm{ac}\end{array}$ & $\begin{array}{l}19.03 \\
\pm \\
1.01 \mathrm{a}\end{array}$ & $\begin{array}{l}9.53 \pm \\
6.29 \mathrm{a}\end{array}$ & $\begin{array}{l}23.00 \pm \\
3.61 \mathrm{a}\end{array}$ & $\begin{array}{l}66.33 \pm \\
5.77 \mathrm{a}\end{array}$ & $\begin{array}{l}8.33 \pm \\
2.89 \mathrm{a}\end{array}$ \\
\hline \multicolumn{2}{|c|}{ Threshold } & NS & NS & $*$ & $*$ & * & NS & NS & NS & NS & $* *$ \\
\hline
\end{tabular}

RBC : Red Blood Cell; Hb : hemoglobin ; PCV : Packed Cell Volume ; MCHC : Mean Corpuscular Haemoglobin Concentration; VGM : Mean Corpuscular Volume; MCH : Mean Corpuscular Haemoglobin ; WBC : White Blood Cell ; PN : Polynuclar neutrophils ; L: Lymphocyte ; M : Monocytes; **: p<0.01; *: p<0.05; NS: Not significant, T: period.. Within a column, values with the same letters are not significantly different between them at the $5 \%$ threshold.

Effects of aqueous extracts of the stem bark of Khaya senegalensis and the leaves of Elaeis guineensis on the biochemical parameters of Wistar rats

The contents of the different biochemical parameters evaluated in Wistar rats are presented in Table 5. The rate of glucose in fasted rats blood decreased, but not significantly throughout the experimental period ( $p>0.05)$ in control rats $(0.75 \mathrm{~g} / \mathrm{l} \pm 0.03$ to $0.56 \mathrm{~g} / \mathrm{l} \pm 0.25)$ and in rats subjected to aqueous extract of the stem bark of Khaya senegalensis $(0.67 \mathrm{~g} / \mathrm{l} \pm 0.19$ to $0.53 \mathrm{~g} / \mathrm{l} \pm 0.20)$. For the same parameter, the content obtained in rats subjected to Elaeis guineensis on day 7 of the experiment $(0.56 \mathrm{~g} / \mathrm{l} \pm 0.03)$ was greater than that obtained in the same rats at the beginning of the 
experiment $(0.45 \mathrm{~g} / \mathrm{l} \pm 0.07)$ and decreased at day $14(0.54 \mathrm{~g} / \mathrm{l} \pm 0.06)$ of the test $(\mathrm{p}>0,05)$. The uremia of control rats and those subjected to aqueous extracts of the leaves of Elaeis guineensis and the stem bark of Khaya senegalensis showed the same trend without significant variation throughout the experimental period $(p>0.05)$. Creatinine content in blood of control rats and those subjected to aqueous extracts of the leaves of Elaeis guineensis and the stem bark of Khaya senegalensis decreased on day 7 of the test followed by a return to normal at the end of the test ( $<<0.05$ ). All experimental group showed a similar trend during the trial. The total blood cholesterol content of control rats and those subjected to aqueous extracts of the leaves of Elaeis guineensis and the stem bark of Khaya senegalensis, it increased on the 7th day of the test, then decreased on the 14th day compared with the normal content $(\mathrm{p}<0.05)$. HDL content in the blood of Wistar rats, it was constant from the beginning of the experiment (D0) to day 7 (0.29 \pm 0.02 to $0.29 \pm 0.09)$, followed by an increase on day $14(0.34 \pm 0.05)$ in control group ( $>0.05)$. For the same parameter, rats subjected to aqueous extracts of the leaves of Elaeis guineensis and the stem bark of Khaya senegalensis recorded a decrease in HDL content on day 7, followed by a return to a level similar to that of day 14 ( $p>0.05)$. No significant variation was observed for GO and GP transaminases in either control group or aqueous extracts of the leaves of Elaeis guineensis and the stem bark of Khaya senegalensis groups throughout the experimental period (Table 5).

Table 5:-Effect of aqueous extracts of the the stem barks of Khaya senegalensis and leaves of Elaeis guineensis on biochemical parameters in Wistar rats

\begin{tabular}{|c|c|c|c|c|c|c|c|c|}
\hline \multirow[b]{2}{*}{ Groups } & \multicolumn{8}{|c|}{ Biochemical parameters } \\
\hline & $\mathbf{T}$ & $\begin{array}{l}\text { Glycemia } \\
(\mathrm{g} / \mathrm{l})\end{array}$ & $\begin{array}{l}\text { Urea } \\
(\mathrm{g} / \mathrm{l})\end{array}$ & $\begin{array}{l}\text { Creatinine } \\
(\mathrm{g} / \mathbf{l})\end{array}$ & $\begin{array}{l}\text { Total } \\
\text { cholestrol }(\mathrm{g} / \mathrm{l})\end{array}$ & HDL & $\begin{array}{l}\text { GOT } \\
\text { (UI/L) }\end{array}$ & $\begin{array}{l}\text { GPT } \\
\text { (UI/L) }\end{array}$ \\
\hline & D0 & $\begin{array}{ll}0.75 & \pm \\
0.03^{\mathrm{a}} & \end{array}$ & $\begin{array}{l}0.29 \\
0.02^{\mathrm{a}}\end{array}=$ & $\begin{array}{ll}8.60 & \pm \\
0.77^{\mathrm{a}} & \pm\end{array}$ & $0.56 \pm 0.03^{\mathrm{a}}$ & $\begin{array}{l}0.29 \\
0.02^{\mathrm{a}}\end{array}$ & $\begin{array}{l}322.27 \quad \pm \\
5.16^{\mathrm{a}}\end{array}$ & $\begin{array}{l}100.17 \quad \pm \\
0.80^{\mathrm{a}}\end{array}$ \\
\hline & D7 & $\begin{array}{l}0.60 \\
0.28^{\mathrm{a}}\end{array}$ & $\begin{array}{l}0.35 \\
0.09^{\mathrm{a}}\end{array}=$ & $\begin{array}{l}6.65 \\
0.71^{\text {ab }}\end{array}$ & $0.96 \pm 0.13^{b}$ & $\begin{array}{ll}0.29 & \pm \\
0.09^{\mathrm{a}} & \end{array}$ & $\begin{array}{ll}286.83 & \pm \\
95.35^{\mathrm{a}} & \end{array}$ & $\begin{array}{l}149.27 \\
59.39^{\mathrm{a}}\end{array}$ \\
\hline & $\begin{array}{l}\text { D1 } \\
4\end{array}$ & $\begin{array}{l}0.56 \\
0.25^{\mathrm{a}}\end{array}$ & $\begin{array}{l}0.23 \\
0.07^{\mathrm{a}}\end{array}=$ & $\begin{array}{l}9.36 \\
1.43^{\mathrm{ac}}\end{array}$ & $0.70 \pm 0.10^{\mathrm{a}}$ & $\begin{array}{l}0.34 \\
0.05^{\mathrm{a}}\end{array}$ & $\begin{array}{l}354.50 \pm 12 \\
7.40^{\mathrm{a}}\end{array}$ & $\begin{array}{l}113.40 \\
15.70^{\mathrm{a}}\end{array}$ \\
\hline \multicolumn{2}{|l|}{ Threshold } & NS & NS & $*$ & $* *$ & NS & NS & NS \\
\hline \multirow{3}{*}{$\begin{array}{l}\text { K. } \\
\text { senegalens } \\
\text { is }\end{array}$} & D0 & $\begin{array}{l}0.67 \\
0.19^{\mathrm{a}}\end{array}$ & $\begin{array}{l}0.25 \\
0.07^{\mathrm{a}}\end{array}$ & $\begin{array}{l}8.46 \\
0.29^{\mathrm{a}}\end{array}$ & $0.59 \pm 0.13^{\mathrm{a}}$ & $\begin{array}{ll}0.35 & \pm \\
0.07^{\mathrm{a}} & \end{array}$ & $\begin{array}{ll}360.17 & \pm \\
28.17^{\mathrm{a}} & \end{array}$ & $\begin{array}{l}83.73 \\
3.06^{\mathrm{a}}\end{array}$ \\
\hline & D7 & $\begin{array}{l}0.54 \\
0.18^{\mathrm{a}}\end{array}$ & $\begin{array}{l}0.27 \\
0.04^{\mathrm{a}}\end{array}=$ & $\begin{array}{l}6.98 \\
0.20^{\mathrm{b}}\end{array}$ & $0.85 \pm 0.08^{b}$ & $\begin{array}{ll}0.28 & \pm \\
0.05^{\mathrm{a}} & \end{array}$ & $\begin{array}{l}306.57 \pm 10 \\
4.37^{\mathrm{a}}\end{array}$ & $\begin{array}{l}83.70 \\
10.88^{\mathrm{a}}\end{array}$ \\
\hline & $\begin{array}{l}\text { D1 } \\
4\end{array}$ & $\begin{array}{l}0.53 \\
0.20^{\mathrm{a}}\end{array}$ & $\begin{array}{l}0.26 \\
0.02^{\mathrm{a}}\end{array}=$ & $\begin{array}{l}9.40 \\
0.87^{\mathrm{a}}\end{array}$ & $0.65 \pm 0.11^{\mathrm{ab}}$ & $\begin{array}{l}0.34 \\
0.05^{\mathrm{a}}\end{array}$ & $\begin{array}{ll}278.50 & \pm \\
58.82^{\mathrm{a}} & \end{array}$ & $\begin{array}{l}86.63 \\
9.63^{\mathrm{a}}\end{array}$ \\
\hline \multicolumn{2}{|l|}{ Threshold } & NS & NS & $* *$ & $*$ & NS & NS & NS \\
\hline \multirow[t]{3}{*}{$\begin{array}{l}\text { E. } \\
\text { Guineensis }\end{array}$} & D0 & $\begin{array}{l}0.45 \\
0.07^{\mathrm{a}}\end{array}$ & $\begin{array}{l}0.27 \\
0.06^{\mathrm{a}}\end{array}$ & $\begin{array}{l}9.31 \\
1.17^{\mathrm{a}}\end{array}$ & $0.71 \pm 0.13^{\mathrm{a}}$ & $\begin{array}{l}0.41 \\
0.11^{\mathrm{a}}\end{array}$ & $\begin{array}{ll}342.70 & \pm \\
75.08^{\mathrm{a}} & \end{array}$ & $\begin{array}{l}76.70 \\
11.45^{\mathrm{a}}\end{array}$ \\
\hline & D7 & $\begin{array}{l}0.56 \\
0.03^{\mathrm{a}}\end{array}$ & $\begin{array}{l}0.31 \\
0.03^{\mathrm{a}}\end{array}=$ & $\begin{array}{l}6.68 \\
0.05^{\mathrm{ab}}\end{array}$ & $0.97 \pm 0.02^{b}$ & $\begin{array}{l}0.33 \\
0.03^{\mathrm{a}}\end{array}$ & $\begin{array}{l}375.60 \\
27.04^{\mathrm{a}}\end{array}$ & $\begin{array}{l}117.00 \quad \pm \\
40.15^{\mathrm{a}}\end{array}$ \\
\hline & $\begin{array}{l}\text { D1 } \\
4\end{array}$ & $\begin{array}{l}0.54 \\
0.06^{\mathrm{a}}\end{array}$ & $\begin{array}{l}0.25 \\
0.05^{\mathrm{a}}\end{array}=$ & $\begin{array}{l}11.83 \\
2.18^{\mathrm{ac}}\end{array}$ & $0.70 \pm 0.05^{\mathrm{a}}$ & $\begin{array}{ll}0.41 & \pm \\
0.01^{\mathrm{a}} & \end{array}$ & $\begin{array}{l}428.20 \\
61.03^{\mathrm{a}}\end{array}$ & $\begin{array}{ll}85.00 & \pm \\
1.04^{\mathrm{a}} & \end{array}$ \\
\hline Threshold & & NS & NS & & * & NS & NS & NS \\
\hline
\end{tabular}

GOT: GO Transaminases; GPT: GP Transaminases. Within a column, values with the same letters are not significantly different between them at the $5 \%$ threshold. $* *$ : $\mathrm{p}<0.01 ; *: \mathrm{p}<0.05$; NS: Not significant, T: period.

Histological study of the liver and kidney of Wistar rats subjected to acute oral toxicity test with aqueous extracts from leaves of Elaeis guineensis and stem bark of Khaya senegalensis Effects of aqueous extract of Khaya senegalensis stem bark and Elaeis guineensis leaves on the liver and kidneys of Wistar rats.

Figure 3 shows histological section of the liver of the control group (I), the group of rats subjected to $2000 \mathrm{mg} / \mathrm{kg}$ of the aqueous extract of Khaya senegalensis stem bark (II) and the group (III) subjected to $2000 \mathrm{mg} / \mathrm{kg}$ of the aqueous extract of the leaves of Elaeis guineensis. No morphological alteration of the histological structure of the livers of Wistar rats subjected to an acute oral toxicity test for aqueous extracts of Khaya senegalensis stem bark (II) and Elaeis guineensis leaves(III) (single dose of $2000 \mathrm{mg} / \mathrm{kg}$ body weight, respectively) was detected compared to the normal histological pattern presented by the control group (I) rats. The parenchyma of the treated rats (Figure II 
and III) showed a typical appearance as that of the control group rats (Fig (I)). Hepatocytes, corded and separated by the sinusoids (S), also showed a similar structure regardless of the lot. The aqueous extracts from various plants used showed no toxic effect on the morphological structure of the liver of Wistar rats at a dose of $2000 \mathrm{mg} / \mathrm{kg}$ in a single oral dose.
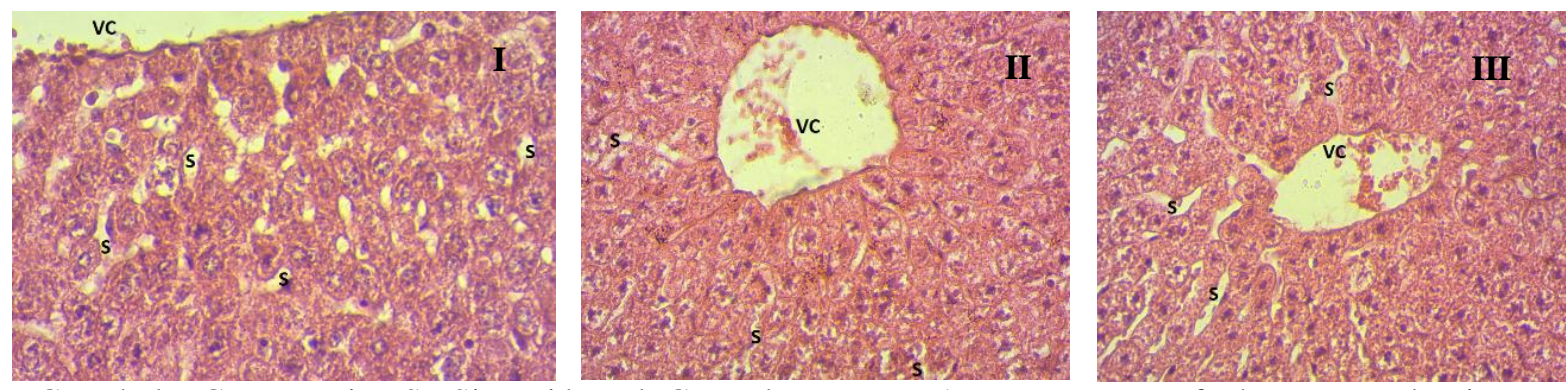

VC: Lobular Centro Vein ; S : Sinusoids ; I l: Control group; II : Aqueous extract of Khaya senegalensis stem bark at $2000 \mathrm{mg} / \mathrm{kg}$; III : Aqueous extract of Elaeis guineensis leaves at $2000 \mathrm{mg} / \mathrm{kg}$.

Figure 3:-Histological section of the liver of Wistar rats

Aqueous extracts of the stem bark of Khaya senegalensis and leaves of Elaeis guineensis on the kidney of Wistar rats

Figure 4 shows the histological analysis of the rats in control group (I), the group subjected to $2000 \mathrm{mg} / \mathrm{kg}$ of the aqueous extract of the stem bark of Khaya senegalensis (II) and the group with $2000 \mathrm{mg} / \mathrm{kg}$ of the aqueous extract of the leaves of Elaeis guineensis (III). Histological analysis showed no morphological alteration of the histological structure of the kidney of Wistar rats subjected to acute oral toxicity tests of the aqueous extracts of the stem bark of Khaya senegalensis (II) and the leaves of Elaeis guineensis (III) $(2000 \mathrm{mg} / \mathrm{kg}$ live weight in a single dose). In addition, no structural differences were detected between histological sections of kidney in group (II) and (III) rats compared to the normal structure of control (I). The renal parenchyma of rats treated with different aqueous extracts of the stem bark of Khaya senegalensis and leaves of Elaeis guineensis exhibited a histological architecture similar to that observed in control group rats (Figure 4 (I)). The glomeruli, proximal tube, distal tube and conductor tube are clearly identifiable. Aqueous extracts of the stem bark of Khaya senegalensis and leaves of Elaeis guineensis doesn't showed toxic activity on the kidney of Wistar rats at a single oral dose of $2000 \mathrm{mg} / \mathrm{kg}$.

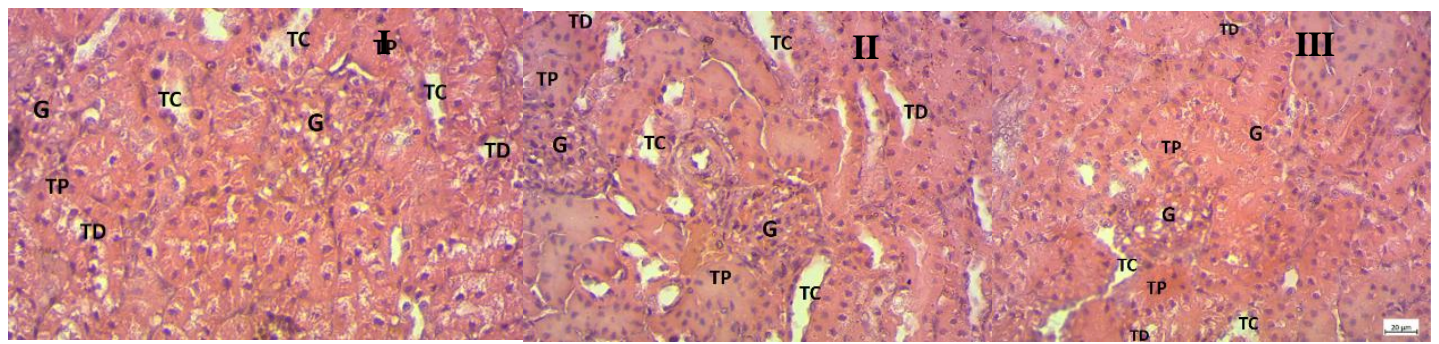

TC: Colector tube, TD: distal tube, TP: proximal tube, G: Glomeruli, I: control group II: Aqueous extract of the stem bark of Khaya senegalensis at 2000mg/kg; III: Aqueous extract of leaves of Elaeis guineensis at $2000 \mathrm{mg} / \mathrm{kg}$.

Figure 4:-Histological section of Wistar rat Kidney

\section{Discussion:-}

Larval cytotoxicity of plant extracts

Our results showed that no larval cytotoxicity was recorded in the use of the aqueous extracts of the leaves of Elaeis guineensis and the stem bark of Khaya senegalensis. According to McLaughlin et al. (1998), the larval toxicity test on Artemia salina larvae assessed the basic toxicity of plant extracts. The cytotoxicity test performed on Artemia salina gave an $\mathrm{LC}_{50}$ of $152.81 \mathrm{mg} / \mathrm{ml}$ for the aqueous extract of leaves of Elaeis guineensis. This lethal concentration 50 shows that the aqueous extract of the leaves of Elaeis guineensis is not toxic at the dose tested. The results are similar to those reported by (Assogba et al., 2015) which reported non-toxicity of the aqueous extract of Elaeis guineensis on Artemia salina. The same test performed on the aqueous extract of the stem bark of Khaya senegalensis revealed an $\mathrm{LC}_{50}$ of $2.69 \mathrm{mg} / \mathrm{ml}$. This concentration reveals the non-cytotoxicity of the aqueous extract 
according to the toxicity grid proposed by (Moshi et al., 2004). This result follows the same logic as those obtained by (Onu et al., 2013).

\section{Phytochemical screening of the stem bark of Khaya senegalensis and leaves of Elaeis guineensis}

Phytochemical screening of the stem bark of Khaya senegalensis revealed tannins, anthocyans, leucoanthocyans, saponins, steroids, and anthracenic derivatives. These different determined compounds are similar to those found by (Takin et al., 2014) which specify that the stem bark of Khaya senegalensis contains a very large amount of phenolic compounds and saponins.

Analysis of the phytochemical compounds of the leaves of Elaeis guineensis showed the presence of tannins, heterosides, saponins, flavonoids, steroids, reducing compound, coumarin, anthracenic derivatives, terpenoids and alkaloids. These results are similar to those found by (Assogba et al., 2015); (Sene et al., 2016); (Yin et al., 2013) and (Sasidharan et al., 2010) confirming the presence of the same chemical compounds in the leaves of Elaeis guineensis. Moreover, (Assogba et al., 2015) state that the aqueous extract of the leaves of Elaeis guineensis is very rich in tannins and saponosides.

Acute oral toxicity of aqueous extracts of the stem bark of Khaya senegalensis and leaves of Elaeis guineensis on Wistar rats

Evaluation of behavioral parameters

Oral administration of a single dose of $2000 \mathrm{mg} / \mathrm{kg}$ of the aqueous extracts of the stem bark of Khaya senegalensis did not cause any behavioral changes (grooming, pelage, tremor, motility, noise reaction, stool appearance) in experimental Wistar rats. These results are similar to those of (Onu et al., 2013) that did not report any change in physical, behavioral, food ingestion, and circulation activities in Wistar rats fed with a $5000 \mathrm{mg} / \mathrm{kg}$ body weight Khaya senegalensis extract. These same authors report that the $\mathrm{LD}_{50}$ would be greater than $5000 \mathrm{mg} / \mathrm{kg}$ live weight; that is confirmed by the $0 \%$ mortality rate obtained in rats fed with the aqueous extract of the stem bark of Khaya senegalensis during this study.

The absence of change in behavior and feeding habits during the 14-day observation of Wistar rats after gavage with the aqueous extract of the leaves of Elaeis guineensis at a dose of $2000 \mathrm{mg} / \mathrm{kg}$ has already been reported by (Anyanji et al., 2013). However, that study took into account the ethanolic extract of leaves of Elaeis guineensis at a concentration of $2 \mathrm{~g} / \mathrm{kg}$.

\section{Effects of aqueous extracts on weight growth in Wistar rats}

Rats subjected to gavage with aqueous extract of the stem bark of Khaya senegalensis bark at $2000 \mathrm{mg} / \mathrm{kg}$ bodyweight showed no signs of toxicity or weight loss. These results corroborate those of (Onu et al., 2013) who reported no influence of the aqueous extract of the stem bark of Khaya senegalensis at $5000 \mathrm{mg} / \mathrm{kg}$ on the physiological parameters of Wistar rats.

The administration of the aqueous extracts of the leaves of Elaeis guineensis at a dose of $2000 \mathrm{mg} / \mathrm{kg}$ had not influence the weight of the rats according to the control group. These results are similar to those reported by (Anyanji et al., 2013) who experienced no change in the body weight during the 14 days of experimentation with an ethanolic extract of Elaeis guineensis at a concentration of $2000 \mathrm{mg} / \mathrm{kg}$ of body weight. The treatment of Wistar rats with the aqueous extract of the leaves of Elaeis guineensis favored the increase of the weight of rats at the 7th day. These results are similar to those obtained by (Rosalina Tan et al., 2011) who made the same observations with the ethanolic leaf extract of Elaeis guineensis administered at $2000 \mathrm{mg} / \mathrm{kg}$ of body weight. (Syahmi et al., 2010) also evaluated the acute oral toxicity of the methanolic extract of the leaves of Elaeis guineensis and reported its nontoxicity at a dose of $5000 \mathrm{mg} / \mathrm{kg}$ of body weight.

Effects of aqueous extracts of the stem bark of Khaya senegalensis and the leaves of Elaeis guineensis on hematological parameters of Wistar rats

The decreasing of Red Blood Cell (RBC), Packed Cell Volume (PCV), lymphocyte, monocyte, and increasing of neutrophil in blood of Wistar rats subjected to aqueous extract of the stem bark of Khaya senegalensis as found in this study were also reported by (Onu et al., 2013). These authors made the same observations with the aqueous extract of the leaves of the same plant. However, the study was a subchronic test performed for 28 days. (Kolawole et al., 2011) also reported decreases in Packed Cell Volume and hemoglobin, as well as in Red Blood Cell following administrations at different concentrations of aqueous extracts of the stem bark of Khaya senegalensis to Wistar rats. 
The increase in the number of white blood cells observed during the present study corroborates the results obtained by (Kolawole et al., 2011).

After 14 days of experimentation, Wistar rats treated with aqueous leaf extract of Elaeis guineensis showed decreasing on lymphocytes, increasing on neutrophils and hematocrit on the 7th day. These results are similar to those of (Anyanji et al., 2013; Kolawole et al., 2011) who made the same observations on Wistar rats subjected to an acute oral toxicity test of ethanolic extract of the leaves of Elaeis guineensis at a concentration of $2000 \mathrm{mg} / \mathrm{kg}$ of body weight. However, contrary to the results of these authors, the reductions in the number of white blood cells obtained during this study are not significant. This difference may be related to the nature of the extract used.

\section{Effects of aqueous extracts of the stem bark of Khaya senegalensis and the leaves of Elaeis guineensis on the biochemical parameters of Wistar rats}

The decrease in glucose content observed in rats gaved with the aqueous extract of the stem bark of Khaya senegalensis is similar to observations made by (Kolawole et al., 2011) who report that aqueous extracts of the stem bark of Khaya senegalensis have anti-hyperglycemic activity thus preventing elevation of glucose levels in the blood. These results also corroborate those obtained by (Takin et al., 2014) who also confirmed the antihyperglycaemic effect through a rat study in which total stem bark extract of Khaya senegalensis decreased hepatic glucose release in Wistar rats. Studies by (Funke and Melzig, 2006) also report the effectiveness of the stem bark of Khaya senegalensis in the control of diabetic disorders, what reinforces thus the results of our study. Administration of the aqueous extract of the stem bark of Khaya senegalensis to Wistar rats favored an increase in urea and creatinine levels in the animals blood on the 7th and 14th day of the experiment, respectively. Our results obtained in this study corroborate those obtained by (Onu et al., 2013) and (Kolawole et al., 2011), which states that levels of urea and creatinine in the blood increase as the concentration of aqueous extract administered to experimental rats' increases. In addition, the marked increasing of urea at day 7 in this study can be linked to high kidney activity or increased catabolism of proteins (Onu et al., 2013). The GO and GP transaminases increased with the administration of the aqueous extract of the stem bark of Khaya senegalensis. These results are similar to those of (Onu et al., 2013) and (Kolawole et al., 2011) who reported an increase in transaminases relative to the corresponding control values after using the aqueous extract of the stem bark of Khaya senegalensis in rats. The increase in GO and GP transaminase levels considered in this study is important and plays an important role in the diagnosis of liver cytolysis (Shahjahan et al., 2004).

According to the aqueous extract of the leaves of Elaeis guineensis, the various biochemical parameters such as blood glucose, uremia, HDL and GO and GP transaminases did not change. This demonstrates the non-toxicity of the aqueous extract of the leaves of Elaeis guineensis used on these rats(Anyanji et al., 2013; Syahmi et al., 2010). The drop in the urea content obtained with the aqueous extract of the leaves of Elaeis guineensis at the 14th day is close to the results of (Rajavel et al., 2012) who reported a significant decrease in urine concentration in diabetic subjects after 12 weeks of treatment with a concentration of $500 \mathrm{mg} / \mathrm{kg}$ of ethanolic extract. Moreover, total cholesterol and High Density Lipoprotein levels decreased during this study. This is similar to the results of (AbdulRazak et al., 2009) who reported that prolonged administration of the aqueous extract of the leaves of Elaeis guineensis reduced the levels of total and HDL cholesterol in the blood of rats. The blood glucose did not change during the whole experimental period, while increased. Similar observation were made in diabetic Wistar rats subjected to a chronic treatment of two to four weeks of the ethanolic extract of the leaves of Elaeis guineensis at doses of $200 \mathrm{mg} / \mathrm{kg}$ and $500 \mathrm{mg} / \mathrm{kg}$ (Rajavel et al., 2012).(Rosalina Tan et al., 2011) reported by the same way, a non-anti-glycemic activity of the ethanolic extract of the leaves of Elaeis guineensis. The non-variation of the results obtained is related to the single administration at a dose of $2000 \mathrm{mg} / \mathrm{kg}$ body weight because according to (Mohamed, 2014) reports that the administration continues over three months of the aqueous extract of the leaves of Elaeis guineensis reduced glucose level in humans. The decrease in cholesterol level on the 7th day of the experiment is in agreement with the results of (Irine et al., 2003) and (Namvar et al., 2009) who state that the aqueous and methanolic extracts of the leaves of Elaeis guineensis have hypo-cholesterolemic properties in rats. Considering the levels of transaminases and creatinine obtained, the results are similar to those obtained by (Rosalina Tan et al., 2011) who demonstrated that administration of the aqueous extract of the leaves of Elaeis guineensis to healthy Wistar rats at varying doses has little influence on transaminase levels. 
Effects of aqueous extracts of the stem bark of Khaya senegalensis and the leaves of Elaeis guineensis on the histological structure of livers and kidneys of Wistar rats

The aqueous extract of the stem bark of Khaya senegalensis showed no structural alterations on the liver and kidneys of animals tested for acute oral toxicity at a single dose of $2000 \mathrm{mg} / \mathrm{kg}$ of body weight. These observations confirm those of (Muhammad et al., 2015; Takin et al., 2014) who reported that the aqueous extract of the stem bark of Khaya senegalensis contains phytochemicals and secondary metabolites that confer hepatoprotective activity against liver damage. Similarly, (Onu et al., 2013) reported the non-toxicity of the aqueous extract of the stem bark of Khaya senegalensis, stating that the aqueous extract maintains intact the histological architecture of the kidneys of Wistar rats subjected to a 28-day chronic toxicity test.(Anyanji et al., 2013) reported that the aqueous extract of the leaves of Elaeis guineensis, used at $2000 \mathrm{mg} / \mathrm{kg}$ body weight, does not cause structural changes in on the liver and kidneys of Wistar rats. Similarly, they point out that no histological changes on the kidney were observed even at high doses of $5000 \mathrm{mg} / \mathrm{kg}$ of body weight. These results were also reported by (Jaffri et al., 2011), who found that catechins extracted from the leaves of Elaeis guineensis protect the liver and kidneys of diabetics from structural and functional damage. Hepatoprotective effects of the ethanolic extract of the leaves of Elaeis guineensis have also been demonstrated by (Sasidharan et al., 2010) and (Vijayarathna and Sasidharan, 2012) with paracetamol-induced lesions after examining the histopathology of mouse liver.

\section{Conclusion:-}

The aqueous extracts of the leaves of Elaeis guineensis and the stem bark of Khaya senegalensis administered at a concentration of $2000 \mathrm{mg} / \mathrm{kg}$ are not toxic in Wistar rats. Larval cytotoxicity has resulted in lethal concentrations greater than $0.1 \mathrm{mg} / \mathrm{ml}$, which justifies that the extracts are non-cytotoxic. The different aqueous extracts don't show cytotoxic activity on the cells and not affect the biochemical and hematological parameters of the experimental Wistar rats. These results justify that Elaeis guineensis and Khaya senegalensis can be used in traditional veterinary medicine in pathological processes without risk of alteration of vital organs as well as biochemical, hematological and physiological constants.

\section{Acknowledgments:-}

We thank the National Fund for Scientific Research and Technological Innovation (FNRSIT) for having financed this work under the name FNRSIT-FC-2015 and members of the Research Unit in Applied Microbiology and Pharmacology of Natural Substances.

\section{Bibliographic references:-}

1. Abdul-Razak, A., Asiedu, A.B., Entsua-Mensah, R.E.M. and DeGraft-johnson, K.a.A. (2009): Assessment of the water quality of the Oti River in Ghana. West Afr. J. Appl. Ecol., 15, 45-60.

2. Anyanji, V.U., Mohamed, S., Zokti, J.A. and Ado, M.A. (2013): Anti-inflammatory properties of oil palm leaf (Elaeis guineensis jacq.) extract in aged rats 5,4 .

3. Assogba, F.M., Aderomou, C., Agbodjogbe, W., Moudachirou, M. and Gbenou, J.D. (2015): Evaluation of diuretic properties from Elaeis guineensis Jacq. (Arecaceae) leaves aqueous extractin Wistar rat.

4. Dassou, G.H., Adomou, A.C., Yédomonhan, H., Ogni, A.C., Tossou, G.M., Dougnon, J.T., Akoègninou, A., 2015. Flore médicinale utilisée dans le traitement des maladies et symptômes animaux au Bénin. J. Anim. Plant Sci., 26: 4036-4057.

5. Dassou, H.G., Ogni, C.A., Yedomonhan, H., Adomou, A.C., Tossou, M., Dougnon, J.T. and Akoegninou, A. (2014): Diversité, usages vétérinaires et vulnérabilité des plantes médicinales au Nord-Bénin. Int. J. Biol. Chem. Sci., 8: 189-210.

6. Dibong, S.D., Ottou, P.B.M., Vandi, D., Ndjib, R.C., Tchamaha, F.M. and Mpondo, E.M. (2015): Ethnobotanique des plantes médicinales anti hémorroïdaires des marchés et villages du Centre et du Littoral Cameroun. J. Appl. Biosci., 96: 9072-9093.

7. Elujoba, A., Odeleye, O. and Ogunyemi, C. (2004): Traditional medicine development for medical and dental primary health care delivery system in Africa. Afr. J. Tradit. Complement. Altern. Med. 2.

8. Funke, I. and Melzig, M.F. (2006): Traditionally used plants in diabetes therapy: phytotherapeutics as inhibitors of alpha-amylase activity. Rev. Bras. Farmacogn., 16: 1-5.

9. Guede-Guina, F., Vangah-Manda, M., Bonga, G.M. and De Souza, C. (1995): Activité antimicrobienne d'un extrait végétal contre les germes opportunistes au cours du SIDA. Rev Med Pharmacol Afr., 1:13-19. 
10. Houndje, E.M.B., Ogni, C.A., Noudeke, N., Farougou, S., Youssao, A.K.I. and Kpodekon, T.M. (2016): Recettes ethno-vétérinaire à base de plantes médicinales utilisées pour le traitement de la fièvre aphteuse au Bénin. Int. J. Biol. Chem. Sci., 10: 2090-2107.

11. Irine, R., Noordin, M.M., Radzali, M., Azizah, H., Hapizah, N., Mahinda, Y.A. and Suhaila, M. (2003): Antioxidant and Hypocholesterolemic Effects of Elaeis guineensis Frond Extract on Hypercholesterolemic Rabbits. Asean Food J., 12: 137-148.

12. Jaffri, J.M., Mohamed, S., Ahmad, I.N., Mustapha, N.M., Manap, Y.A., Rohimi, N. (2011): Effects of catechinrich oil palm leaf extract on normal and hypertensive rats' kidney and liver. Food Chem., 128: 433-441.

13. Kawsar, S.M.A., Huq, E., Nahar, N. (2008): Cytotoxicity Assessment of the Aerial Parts of Macrotyloma uniflorum Linn. Int. J. Pharmacol., 4: 297-300.

14. Kiernan, J.A. (2015): Histological and histochemical methods: theory and practice, 5th edition. ed. [Place of publication not identified] Scion.

15. Kolawole, S.O., Kolawole, O.T. and Akanji, M.A. (2011): Effects of Aqueous Extract of Khaya senegalensis Stem Bark on Biochemical and Hematological Parameters in Rats. J. Pharmacol. Toxicol., 6: 602-607.

16. Kouchade, S.A., Adomou, C.A., Dassou, G.H. and Akoegninou, A. (2017): Facteurs socioculturels et environnementaux déterminant la connaissance des plantes utilisées pour les soins infantiles au Sud du Bénin. Int. J. Biol. Chem. Sci., 11: 1272-1287.

17. Mat Ali, R., Houghton, P.J., Raman, A. and Hoult, J.R.S. (1998): Antimicrobial and antiinflammatory activities of extracts and constituents of Oroxylum indicum (L.) Vent. Phytomedicine, 5: 375-381.

18. Mohamed, S. (2014): Oil Palm Leaf: A New Functional Food Ingredient for Health and Disease Prevention. J. Food Process. Technol., 05.

19. Moshi, M.J., Cosam, J.C., Mbwambo, Z.H., Kapingu, M. and Nkunya, M.H.H. (2004): Testing Beyond Ethnomedical Claims: Brine Shrimp Lethality of Some Tanzanian Plants. Pharm. Biol., 42: 547-551.

20. Muhammad, I., Alhassan, A., Wudil, A. and Jarumi, I. (2015): Toxicological and Protective Effect of Aqueous Stem Bark Extract of Khaya senegalensis (ASBEKS) on Liver of Experimental Rat. Br. J. Appl. Sci. Technol., 9: 600-605.

21. Namvar, F., Mohamed, S., Behravan, J., Mohamed Mustapha, N., Mohammed Alitheen, N.B. and Othman, F. (2009): Estrogenic activity of Elaeis guineensis leaf. Pharmacologyonline, 2: 818-826.

22. Noudèkè, N.D., Dotché, I., Ahounou, G.S., Karim, I.Y.A. and Farougou, S. (2017): Inventory of medicinal plants used in the treatment of diseases that limit milk production of cow in Benin. J. Adv. Vet. Anim. Res., 4: $1-14$.

23. OECD guideline 423. Test No. 423: Acute Oral toxicity - Acute Toxic Class Method | READ online [WWW Document]. OECD ILibrary. URL https://read.oecd-ilibrary.org/environment/test-no-423-acute-oral-toxicityacute-toxic-class-method_9789264071001-en (accessed 9.14.19).

24. Onu, A., Saidu, Y., Ladan, M.J., Bilbis, L.S., Aliero, A.A. and Sahabi, S.M. (2013): Effect of Aqueous Stem Bark Extract of Khaya senegalensis on Some Biochemical, Haematological, and Histopathological Parameters of Rats. J. Toxicol., 2013: 1-9.

25. Rajavel, V., Abdul Sattar, M.Z., Abdulla, M.A., Kassim, N.M. and Abdullah, N.A. (2012): Chronic Administration of Oil Palm (Elaeis guineensis) Leaves Extract Attenuates Hyperglycaemic-Induced Oxidative Stress and Improves Renal Histopathology and Function in Experimental Diabetes. Evid. Based Complement. Alternat. Med., 1-12.

26. Rosalina Tan, R.T., Mohamed, S., Samaneh, G.F., Noordin, M.M., Goh, Y.M. and Manap, M.Y. (2011): Polyphenol rich oil palm leaves extract reduce hyperglycaemia and lipid oxidation in STZ-rats 9.

27. Sasidharan, S., Nilawatyi, R., Xavier, R., Latha, L.Y. and Amala, R. (2010): Wound healing potential of Elaeis guineensis Jacq leaves in an infected albino rat model. Mol. Basel Switz., 15: 3186-3199.

28. Sene, Madièye, Ndiaye, M., Barboza, F.S., Sene, Mbaye, Diatta, W., Sarr, A., Ndiaye-Sy, A., Dieye, A.M., Sy, G.Y. (2016): Activité anti-inflammatoire de l'extrait aqueux des feuilles de Elaeis guineensis Jacq. (ARECACEAE) sur l'oedème aigu de la patte de rat induit par la carraghènine. Int. J. Biol. Chem. Sci., 10: 2568-2574.

29. Shahjahan, M., Sabitha, K.E., Jainu, M. and Shyamala Devi, C.S. (2004): Effect of Solanum trilobatum against carbon tetrachloride induced hepatic damage in albino rats. Indian J. Med. Res., 120: 194-198.

30. Sidi, I.Y.M.S., Olounladé, P.A., Yaoitcha, A., Dedehou, V.F.G.N., Alowanou, G.G., Azando, E.V.B. and Hounzangbé-Adoté, M.S. (2017): Principales espèces médicinales utilisées en médecine vétérinaire au Bénin: disponibilité et caractéristiques dendrométriques. Bull. Anim. Health Prod. Afr., 65: 209-220.

31. Smith, A. and Bruton, J.W. (1977): Color atlas of histological staining techniques. Year Book Medical Pub. 
32. Syahmi, A.R.M., Vijayarathna, S., Sasidharan, S., Latha, L.Y., Kwan, Y.P., Lau, Y.L., Shin, L.N. and Chen, Y. (2010): Acute oral toxicity and brine shrimp lethality of Elaeis guineensis Jacq., (oil palm leaf) methanol extract. Mol. Basel Switz., 15: 8111-8121.

33. Takin, M., M, A., L, Z., E, Assou., N, A. and Agossou, A.S. (2014): Effect of total Khaya senegalensis (Meliaceae) barks extracts on hepatic liberation of glucose. Natl. J. Physiol. Pharm. Pharmacol., 4: 112.

34. Umar, I.A., Ibrahim, M.A., Fari, N.A., Isah, S. and Balogun, D.A. (2010): In-vitro and -vivo anti-Trypanosoma evansi activities of extracts from different parts of Khaya senegalensis. J. Cell Anim. Biol., 4: 91-95.

35. Vijayarathna, S. and Sasidharan, S. (2012): Cytotoxicity of methanol extracts of Elaeis guineensis on MCF-7 and Vero cell lines. Asian Pac. J. Trop. Biomed., 2: 826-829.

36. Yin, N.S., Abdullah, S. and Phin, C.K. (2013): Phytochemical constituents from leaves of elaeis guineensis and their antioxidant and antimicrobial activities. 